\title{
Dietary calcium does not reduce experimental colorectal carcinogenesis after small bowel resection despite reducing cellular proliferation
}

\author{
G H Barsoum, H Thompson, J P Neoptolemos, M R B Keighley
}

Academic Department of Surgery, Queen Elizabeth Hospital, Birmingham G H Barsoum

J P Neoptolemos

M R B Keighley

Academic Department of Pathology, General

Hospital, Birmingham

H Thompson

Correspondence to:

Mr J P Neoptolemos,

Academic Department of

Surgery, Dudley Road

Surgery, Dudley Road
Hospital, Birmingham

Hospital, Birn.
B18 7QH.

Accepted for publication

6 April 1992

Figure 1: Experimental design. $D M H=1,2$

dimethylhydrazine; $S B R=$

small bowel resection; $C A=$ calcium.

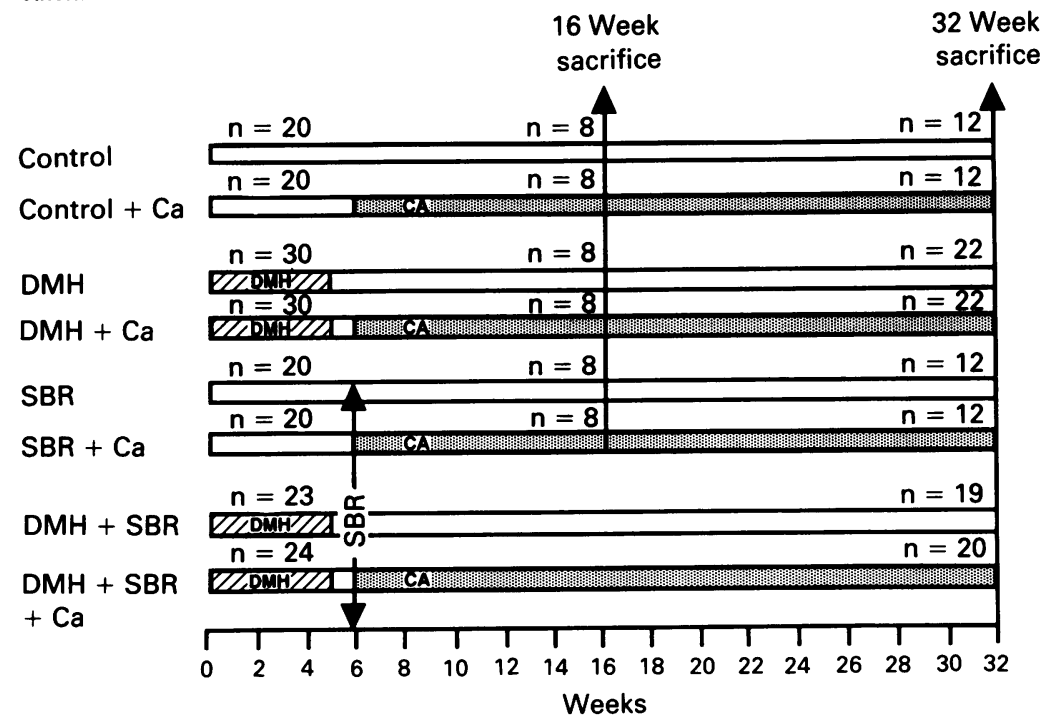

diet, particularly one that is high in animal fat, seems to have a major influence on the development of colorectal cancer. ${ }^{\prime 2}$ Yet a population with a high dietary intake of fat, protein, and meat can also be at very low risk of colorectal cancer. ${ }^{3}$ One of the factors that may be protective is calcium, ${ }^{+}$but the epidemiological data are contentious. ${ }^{5}$ Therefore, some investigators have examined the role of dietary calcium in influencing colonic crypt cell kinetics, since the latter may be a marker of neoplastic predisposition. ${ }^{610}$

Williamson and Rainey (among others) have proposed that conditions which increase intestinal cell proliferation also protentiate intestinal carcinogenesis." Under experimental conditions, hyperplasia follows $20-80 \%$ of small bowel resection, ${ }^{1213}$ jejunoileal bypass, ${ }^{1+15}$ subtotal colectomy, ${ }^{16}$ colostomy closure, ${ }^{17}$ pancreaticobiliary diversion, ${ }^{13}$ and topical instillation of bile acids. ${ }^{18}$ These manoeuvres are all associated with increased colonic tumourigenesis. $1{ }^{19-22}$ In man, there seems to be an expanded colonic crypt cell proliferative compartment in a number of situations associated with an increased risk of colorectal cancer, including in subjects with a family history of colorectal cancer ${ }^{23}$ and in patients with ulcerative colitis, ${ }^{2+}$ as well as those with sporadic adenoma or cancer ${ }^{1025}$ and those with familial adenomatous polyposis. ${ }^{23}$

It is of interest that supplementary calcium is able to abolish the increased tumour yield after enterectomy ${ }^{26}$ and will also reduce crypt cell production. ${ }^{27}$ While the evidence linking increased cell proliferation and colorectal cancer is good, the converse is less clear cut. Moreover, one experimental study showed increased tumour formation with dietary calcium..$^{2 x}$ To help clarify some of these issues, a single experimental study was undertaken to compare. the effects of dietary calcium and $70 \%$ small bowel resection on experimental colonic tumourigenesis and crypt cell proliferation in the terminal ileum, caecum, and distal colon, thereby permitting multivariate statistical analysis to determine independently significant and interacting factors influencing mucosal proliferation.

\section{Methods}

STUDY DESIGN (FIG 1)

\section{(a) Effect of dietary calcium on normal small and} large bowel mucosa proliferation

Forty animals were randomly divided into two equal groups of which one group received calcium supplementation. Eight animals from 
each group were killed at 16 weeks and the remainder at 32 weeks.

\section{(b) Effect of dietary calcium and 1,2} dimethylhydrazine on small and large bowel mucosa proliferation

Sixty animals received 1,2 dimethylhydrazine and were divided into two equal groups, of which one group received calcium supplementation. Eight animals from each group were killed at 16 weeks and the remainder ( 22 per group) were sacrificed at 32 weeks.

\section{(c) Effect of dietary calcium, 1,2}

dimethylhydrazine, and 70\% small bowel resection on small and large bowel mucosa proliferation

Eighty seven animals underwent $70 \%$ small bowel resection and were divided into two groups. In the first group $(n=40)$, half received calcium supplementation $(n=20) ; 16$ animals (eight receiving calcium) were sacrificed at 16 weeks; the remainder were sacrificed at 32 weeks. The second group $(n=47)$ received 1,2 dimethylhydrazine, and 24 randomly chosen animals were given calcium supplementation. Four of these animals were lost for technical reasons and four because of intestinal obstruction; the remainder $(n=39)$ were killed at 32 weeks.

The crypt cell production rates (CCPR) were determined at each point of sacrifice. For 24 hours before sacrifice at 32 weeks, animals were placed in metabolism cages and a 24 hour stool collection was performed for faecal fat measurement. At the time of sacrifice, blood was obtained for measurement of serum calcium, phosphate, and albumin. Finally, the intestinal tract was excised, fixed in formalin, stained with haematoxylin and eosin, then coded.

\section{ANIMALS, CALCIUM INTAKE, AND CALCIUM} SUPPLEMENTATION

Female Wister rats (Charles Rivers, UK, Ltd) weighing $100-150 \mathrm{~g}$ were housed in the Biomedical Services Unit (University of Birmingham) with a 12 hour regular light-dark cycle. The animals were weighed weekly and given food (diet 86A, Pilsbury Ltd, UK, containing $19 \%$ protein, $3.4 \%$ fibre, and $0.8 \%$ calcium) and water ( $6 \mathrm{mg}$ calcium carbonate/l, Severn Trent Water Authority) ad libitum, which was recorded daily. The normal average dietary calcium intake was $140 \mathrm{mg} / 24$ hours which was doubled to $280 \mathrm{mg} / 24$ hours in the above specified groups by the addition of calcium lactate to the drinking water. Calcium supplementation was begun in all the relevant groups at six weeks.

\section{CARCINOGENESIS}

This was induced with subcutaneous 1,2 dimethylhydrazine (Aldrich Chemical Co Ltd) $40 \mathrm{mg} / \mathrm{kg}$ body weight, weekly for five weeks. Controls received carrier solution (saline/ EDTA).
SMALL BOWEL RESECTION

A $70 \%$ small bowel resection was performed under general anaesthesia after measuring the small bowel and preserving the distal $10 \mathrm{~cm}$ of ileum. An end to end anastomosis was formed using a single layer of interrupted $6 / 0$ silk.

\section{CCPR}

A previously in vivo stathmokinetic method was employed. ${ }^{29}{ }^{30}$ Under halothane anaesthesia, six to eight animals were killed serially at 15-30 minute intervals for 135-180 minutes, after intraperitoneal administration of vincristine (Oncovin, Eli-Lilly, Basingstoke, UK) $1 \mathrm{mg} / \mathrm{kg}$ body weight. Mucosa was obtained from the caecum, distal colon $2 \mathrm{~cm}$ from the anus, and the terminal ileum $5 \mathrm{~cm}$ from the ileocaecal valve. The number of metaphase arrest figures were counted from 30 crypts at each site in the large bowel and from 10 crypts in the small bowel. The CCPR (cells/crypt/hour) was determined by the slope of the regression line comparing the number of mitotic figures with time.

SERUM CALCIUM, PHOSPHATE, AND ALBUMIN

This was determined by automated analysis in the Department of Chemical Pathology using a SMAC machine.

\section{FAECAL FAT ANALYSIS}

The fats were saponified with $5 \%$ alcoholic potassium hydroxide, extracted with $\mathrm{HCl}$ and ether, then measured calorimetrically. ${ }^{31}$

\section{HISTOLOGICAL ANALYSIS}

The slides were examined by a consultant pathologist (HT) who was unaware of the group origin of the tissue. Tumours were assessed as benign or malignant and were graded by degree of dysplasia (benign) or differentiation (malignant).

\section{ETHICAL CONSIDERATIONS}

The studies were undertaken under Home Office and University of Birmingham regulations ensuring the humane treatment of animals at all times.

TABLE I Mean (SD) animal weights at 16 and 32 weeks (the starting weights were all similar-mean $133 \mathrm{~g}(17) \mathrm{g}$, range $100-150 \mathrm{~g}$ )

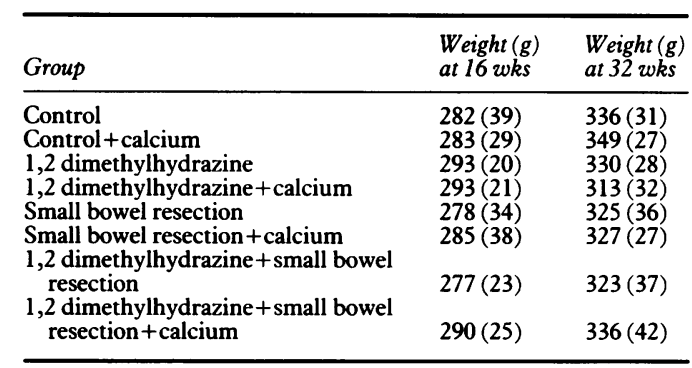

None of the groups was significantly different from the others at each of the time points. 
TABLE II Summary of the number and site of tumours in the different groups receiving 1,2 dimethylhydrazine

\begin{tabular}{|c|c|c|c|c|c|c|c|}
\hline \multirow[b]{2}{*}{ Group } & \multirow{2}{*}{$\begin{array}{l}\text { No of } \\
\text { animals }\end{array}$} & \multirow{2}{*}{$\begin{array}{l}\text { No with } \\
\text { tumours }\end{array}$} & \multirow{2}{*}{$\begin{array}{l}\text { Total no of } \\
\text { GI tumours }\end{array}$} & \multicolumn{4}{|c|}{ No of tumours at each site } \\
\hline & & & & Colon & Duodenum & Anastomosis & Other \\
\hline \multirow{3}{*}{$\begin{array}{l}1,2 \text { dimethylhydrazine } \\
1,2 \text { dimethylhydrazine }+ \text { calcium } \\
1,2 \text { dimethylhydrazine }+ \text { small bowel resection } \\
1,2 \text { dimethylhydrazine }+ \text { small bowel resection }+ \\
\text { calcium }\end{array}$} & $\begin{array}{l}22 \\
22\end{array}$ & $\begin{array}{r}13 \\
5\end{array}$ & $\begin{array}{l}26(11)^{\star} \\
11(3)\end{array}$ & $\begin{array}{l}24(11)^{\star} \\
8(3)\end{array}$ & $\begin{array}{l}2 \\
2\end{array}$ & $\begin{array}{l}0 \\
0\end{array}$ & \\
\hline & 21 & 11 & $17(3)$ & $15(3)$ & 1 & 1 & $1 \neq(1) \mathbb{8}$ \\
\hline & 22 & 15 & $25(5)$ & $18(4)$ & $4(1)$ & 3 & 0 \\
\hline
\end{tabular}

$\star^{\star}$ Numbers in parentheses are benign tumours; †renal carcinoma; łmiddle ear carcinoma; §mammary adenoma.

STATISTICAL ANALYSIS

Categorical data were analysed by the $\chi^{2}$ test, and non-parametric continuous data by the Kruskall-Wallis and Mann-Whitney U (two tailed) tests. The data relating to CCPR were analysed using the Statistical Package for the Social Sciences (SPSS). Independently significant effects were investigated using a repeated measures analysis of variance (ANOVA). The within subjects repeated measures on crypt cell production were the three different sites (ileum, caecum, and distal colon) and the between subject factors were calcium, 1,2 dimethylhydrazine, and small bowel resection. All possible interactions were also tested for independent significance. For descriptive purposes the CCPR is given as the slope ( $\pm S E M)$ of each regression line; the $\mathbf{R}-\mathrm{sq} \%$ is also given, which represents the extent to which each data set is described by a straight line. Unless stated otherwise, signific ance was set at $\mathrm{p}<0.05$.

\section{Results}

Figure 2: Tumour yield at 32 weeks of sacrifice.

There were no significant differences between

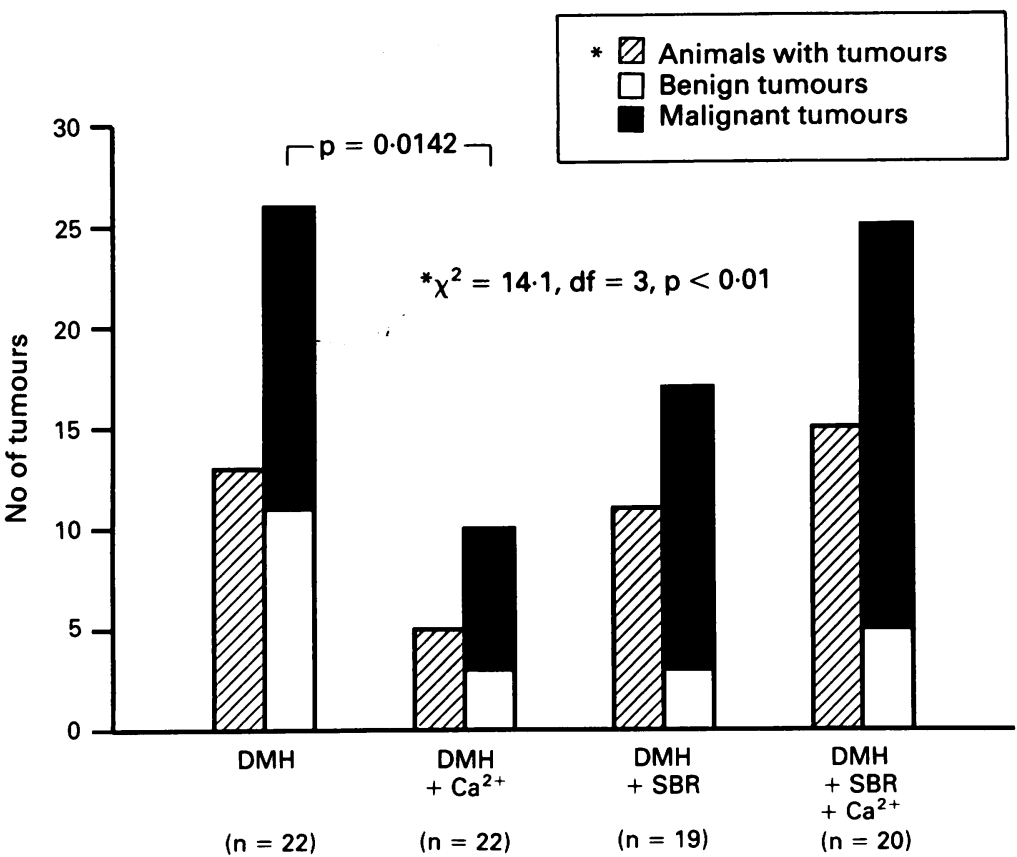

TABLE III The mean (SEM) crypt cell production rate in units of cells/crypt/h $(R-s q \%)$ in the different groups at different sites of the bowel, sacrificed at 16 weeks

\begin{tabular}{llrl}
\hline Group & Ileum & Caecum & Distal colon \\
\hline Control & $20 \cdot 9(1 \cdot 5)(97 \cdot 2 \%)$ & $11 \cdot 2(0 \cdot 6)(98 \cdot 1 \%)$ & $5 \cdot 2(0 \cdot 4)(95 \cdot 8 \%)$ \\
Control + calcium & $22 \cdot 1(2 \cdot 0)(95 \cdot 5 \%)$ & $7 \cdot 8(0 \cdot 4)(98 \cdot 2 \%)$ & $5 \cdot 3(0 \cdot 2)(99 \cdot 5 \%)$ \\
1,2 dimethylhydrazine & $25 \cdot 9(2 \cdot 9)(94 \cdot 0 \%)$ & $12 \cdot 4(0 \cdot 7)(98 \cdot 1 \%)$ & $8 \cdot 7(0 \cdot 8)(91 \cdot 5 \%)$ \\
1,2 dimethylhydrazine+calcium & $25 \cdot 4(2 \cdot 0)(97 \cdot 1 \%)$ & $6 \cdot 1(0 \cdot 8)(96 \cdot 0 \%)$ & $6 \cdot 4(0 \cdot 6)(95 \cdot 5 \%)$ \\
Small bowel resection & $39 \cdot 3(3 \cdot 9)(95 \cdot 4 \%)$ & $12 \cdot 8(0 \cdot 5)(99 \cdot 3 \%)$ & $9 \cdot 9(1 \cdot 2)(89 \cdot 1 \%)$ \\
Small bowel resection + calcium & $23 \cdot 7(2 \cdot 8)(91 \cdot 0 \%)$ & $9 \cdot 1(0 \cdot 6)(95 \cdot 5 \%)$ & $8 \cdot 9(0 \cdot 6)(95 \cdot 3 \%)$ \\
\hline
\end{tabular}

any of the animal groups with respect to weight (Table I).

\section{TUMOUR YIELD}

There was a significant reduction of tumours in the group receiving calcium supplementation and 1,2 dimethylhydrazine compared with the group receiving 1,2 dimethylhydrazine alone (Fig 2). There were no significant differences with regard to the proportions of benign or malignant tumours or their distribution (Table II). There were no significant differences in respect of the degree of dysplasia or the histological grades or stages (data not shown).

\section{CCPR AT 16 WEEKS}

The results are shown in Table III and the statistical analysis in Table IV. The bowel site had the greatest effect on crypt cell production (ileum $>$ caecum $>$ distal colon). Calcium, 1,2 dimethylhydrazine, and small bowel resection all had independently significant effects on crypt cell production at this time and there was a significant interaction between the site of the gut and small bowel resection. Both 1,2 dimethylhydrazine and small bowel resection individually increased CCPR while calcium generally reduced this, in a simple arithmetic manner (that is, there was no interaction).

\section{CCPR AT 32 WEEKS}

The results are shown in Table $\mathrm{V}$, and the statistical analysis in Table VI. The independently significant effects found at 16 weeks were maintained at 32 weeks. Moreover, the additional groups at 32 weeks allowed testing of interactions between calcium, 1,2 dimethylhydrazine, and small bowel resection, revealing two way but not three way interactions. There was also a highly significant reduction in CCPRs at all sites from 16 weeks to 32 weeks $(p<0.001)$ upon which the above changes were superimposed.

SERUM CALCIUM, PHOSPHATE, AND ALBUMIN None of the results were significantly different between the groups (Table VII; p set at $<0.02$ because of multiple testing).

\section{FAECAL FAT EXCRETION}

Calcium increased faecal fat excretion in two of the three pairs of groups in which this was measured (Table VIII; $p$ set at $<0.02$ because of multiple testing). 


\section{Discussion}

Our results are consistent with observations in man that mucosal proliferation decreases with distance from the ileocaecal valve to the rectum. ${ }^{252}$ Two previous experimental studies have shown an opposite effect, ${ }^{33}{ }^{34}$ which may be due to the different species or sex of animals used and the methods of assessing cellular proliferation (stathmokinetic technique $v$ labelling index using tritiated thymidine). In agreement with

TABLE IV Tests (ANOVA) for between and within subjects effects using unique SS on the production of crypt cells at 16 weeks sacrifice

\begin{tabular}{llrc}
\hline Source & $d f$ & F ratio & p value \\
\hline Between subjects: & 1 & & \\
Calcium & 1 & $9 \cdot 3$ & $0 \cdot 011$ \\
1,2 dimethylhydrazine x site & 1 & $58 \cdot 2$ & $<0 \cdot 001$ \\
Small bowel resection & 1 & $119 \cdot 3$ & $<0 \cdot 001$ \\
Calcium x 1,2 dimethylhydrazine & 1 & $0 \cdot 1$ & $\mathrm{NS}$ \\
Calcium x small bowel resection & 2 & $2 \cdot 1$ & $\mathrm{NS}$ \\
Within subjects: & 2 & $524 \cdot 7$ & $\mathrm{~N}$ \\
Site & 2 & $1 \cdot 2$ & $\mathrm{NS} \ddagger$ \\
Calcium x site & 2 & $28 \cdot 4$ & $\mathrm{NS}$ \\
1,2 Dimethylhydrazine x site & 2 & $1 \cdot 6$ & $\mathrm{NS}$ \\
Small bowel resection x site & $2 \cdot 7$ & $\mathrm{NS}$ \\
Calcium x 1,2 dimethylhydrazine x site & 2 & & \\
Calcium x small bowel resection x site & 2 & & \\
\hline
\end{tabular}

Site refers to ileum, caecum, and distal colon; ' $x$ ' denotes interaction; $\ddagger$ significant using pooled MSE $(\mathrm{F}=4 \cdot 3, \mathrm{p}=0 \cdot 019)$.

TABLE V The mean (SEM) crypt cell production rate in units of cells/crypt/h $(R-s q \%)$ in the different groups at different sites of the bowel, sacrificed at 32 weeks

\begin{tabular}{|c|c|c|c|}
\hline Group & Ileum & Caecum & Distal colon \\
\hline ont & & & \\
\hline$+c$ & & & \\
\hline ,2 & & & \\
\hline , & & $9 \%)$ & 3. \\
\hline $\mathrm{Sm}$ & & $\%)$ & 11 \\
\hline \multirow{3}{*}{$\begin{array}{l}\text { Small bowel resection }+ \text { calcium } \\
1,2 \text { dimethylhydrazine }+ \text { small bowel } \\
\text { resection } \\
1,2 \text { dimethylhydrazine }+ \text { small bowel } \\
\text { resection + calcium }\end{array}$} & & & 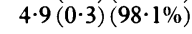 \\
\hline & $21 \cdot 2(1 \cdot 3)(98 \cdot 4 \%)$ & $12 \cdot 0(1 \cdot 0)(98 \cdot 1 \%)$ & $9 \cdot 5(0.9)(95 \cdot 6 \%)$ \\
\hline & & & \\
\hline
\end{tabular}

TABLE VI Tests (ANOVA) for between and within subjects effects using unique SS on the production of crypt cells at 32 weeks sacrifice

\begin{tabular}{|c|c|c|c|}
\hline Source & $d f$ & F ratio & pvalue \\
\hline \multicolumn{4}{|l|}{ Between subjects: } \\
\hline Calcium & 1 & $64 \cdot 6$ & $<0.011$ \\
\hline 1,2 dimethylhydrazine & 1 & $14 \cdot 8$ & 0.002 \\
\hline Small bowel resection & 1 & $54 \cdot 5$ & $<0.001$ \\
\hline 1,2 dimethylhydrazine $x$ small bowel resection & 1 & $12 \cdot 4$ & 0.003 \\
\hline Calcium $\times 1,2$ dimethylhydrazine & 1 & $7 \cdot 8$ & $0 \cdot 014$ \\
\hline Calcium $\mathrm{x}$ small bowel resection & 1 & $3 \cdot 8$ & NS \\
\hline Calcium $x 1,2$ dimethylhydrazine $x$ small bowel resection & 1 & $0 \cdot 7$ & NS \\
\hline \multicolumn{4}{|l|}{ Within subjects: } \\
\hline Site & 2 & $2019 \cdot 4$ & $<0 \cdot 001$ \\
\hline Calcium $\mathrm{x}$ site & 2 & $28 \cdot 3$ & $<0.001$ \\
\hline 1,2 dimethylhydrazine $x$ site & 2 & $11 \cdot 4$ & $<0.001$ \\
\hline Small bowel resection $\mathrm{x}$ site & 2 & $86 \cdot 5$ & $<0.001$ \\
\hline 1,2 dimethylhydrazine $\mathrm{x}$ small bowel resection $\mathrm{x}$ site & 2 & $41 \cdot 2$ & $<0.001$ \\
\hline Calcium $x 1,2$ dimethylhydrazine $x$ site & 2 & $15 \cdot 5$ & $<0.001$ \\
\hline Calcium $\mathrm{x}$ small bowel resection $\mathrm{x}$ site & 2 & $1 \cdot 8$ & NS \\
\hline Calcium $\times 1,2$ dimethylhydrazine $x$ small bowel resection $x$ site & 2 & $1 \cdot 2$ & NS \\
\hline
\end{tabular}

Site refers to ileum, caecum, and distal colon; ' $x$ ' denotes interaction.

TABLE VII Results of mean (SD) serum calcium, phosphate, and albumin at 16 weeks

\begin{tabular}{llll}
\hline Group & $\begin{array}{l}\text { Calcium } \\
(\text { mmolll })\end{array}$ & $\begin{array}{l}\text { Albumin } \\
(\mathrm{g} / l)\end{array}$ & $\begin{array}{l}\text { Phosphate } \\
(\text { mmolll })\end{array}$ \\
\hline Control & $2 \cdot 66(0 \cdot 16)$ & $36 \cdot 5(3 \cdot 9)$ & $2 \cdot 04(0 \cdot 27)$ \\
Control+calcium & $2 \cdot 75(0 \cdot 16)$ & $35 \cdot 7(3 \cdot 0)$ & $2 \cdot 20(0 \cdot 30)$ \\
1,2 dimethylhydrazine & $2 \cdot 76(0 \cdot 08)$ & $39 \cdot 7(3 \cdot 2)$ & $1 \cdot 73(0 \cdot 23)$ \\
1,2 dimethylhydrazine+calcium & $2 \cdot 84(0 \cdot 16)$ & $39 \cdot 0(3 \cdot 4)$ & $1 \cdot 91(0 \cdot 50)$ \\
Small bowel resection & $2 \cdot 96(0 \cdot 11)$ & $37 \cdot 0(3 \cdot 7)$ & $3 \cdot 82(1 \cdot 11)$ \\
Small bowel resection+calcium & $2 \cdot 84(0 \cdot 15)$ & $35 \cdot 0(4 \cdot 4)$ & $2 \cdot 28(0 \cdot 41)$ \\
\hline
\end{tabular}

All comparisons NS earlier studies, both carcinogen administration $^{26} 33$ and $80 \%$ small bowel resection ${ }^{27}$ increased the colonic CCPR, whereas supplementary calcium had the opposite effect." Between 16 and 32 weeks, the CCPR became significantly decreased at all three intestinal sites. Time had a greater effect on reducing the CCPR than did dietary calcium. Two other experimental studies ${ }^{1533}$ have shown an increase in the CCPR with age, but studies in man are variable. ${ }^{35}{ }^{36}$ Our data are also consistent with observations in man that mucosal proliferation is increased in patients with large adenomas or cancer. ${ }^{1025}$ Since colorectal cancer is distributed predominantly in the distal large bowel and rectum where the CCPR is least, additional factors to those which cause cell proliferation may be important for tumourigenesis.

The latter notion is further supported by the tumour yields in the different groups, which did not always correlate with the mucosal proliferation rates (compare Fig 2 and Table V). For example, the tumour yields in the 1,2 dimethylhydrazine group and the 1,2 dimethylhydrazine plus small bowel resection plus calcium group were very similar but the distal colonic CCPR differed by a factor of $\times 2$. Of three previous studies involving 30-85\% enterectomy, two showed an increase in tumour yield ${ }^{21}$ it and one, no difference. ${ }^{16}$ Hart et $a l^{21}$ administered 1,2 dimethylhydrazine $(20 \mathrm{mg} / \mathrm{kg})$ weekly for a total of 16 weeks ( 12 weeks after enterectomy) and at sacrifice at 50 weeks, the increase in tumours was at the anastomosis and not in the colon. Using Fischer rats given a total dose of $90 \mathrm{mg} / \mathrm{kg}$ azoxymethane, Williamson et $a l^{16}$ found no increase in tumours in the group that had $85 \%$ enterectomy and attributed this to poor weight gain, since body mass influences carcinogenesis. In the present study there were no significant differences in body weight at the time of sacrifice so this is not the explanation for the discrepancy in tumour yield between this and the two other studies. ${ }^{2126}$ Williamson and Rainey have made the important observation that ileal resection reduces the latent period for tumour formation but not the overall tumour yield."

Appleton et al have indicated that the mucosal proliferative changes brought about in experimental carcinogenesis by small bowel resection or calcium supplementation, or both, are closely linked to tumour yield. ${ }^{26}$ This conclusion was based on sophisticated but completely separate experiments. ${ }^{26} 27$ In the first study, CCPR was measured in 58 male Sprague-Dawley rats (mean (SD) starting weight $358(25)$ g) sacrificed seven weeks after an $80 \%$ small bowel resection or

TABLE VIII Results of mean (SD) total faecal fat excretion at 32 weeks

\begin{tabular}{lc}
\hline Group & $\begin{array}{l}\text { Total faecal fat } \\
(\mu \mathrm{mol} / \mathrm{g})\end{array}$ \\
\hline Control & $50(10)^{\star}$ \\
Control + calcium & $103(20) \dagger$ \\
Small bowel resection & $65(20) \ddagger$ \\
Small bowel resection + calcium & $113(20) \Phi$ \\
1,2 dimethylhydrazine + small bowel resection & $80(10)$ \\
1,2 dimethylhydrazine+ small bowel resection + & $100(20)$ \\
\hline
\end{tabular}

* $v \dagger \mathrm{p}<0 \cdot 01 ; \ddagger v \S \mathrm{p}<0 \cdot 01 ;$ all other comparisons NS. 
transection and with or without calcium supplementation; no carcinogen was given. ${ }^{27}$ In the second study, tumour yield (but not CCPR) was determined in 53 similar animals (mean (SD) starting weight $150(14) \mathrm{g}$ ) given azoxymethane for six weeks before using an identical protocol, but delaying sacrifice until 25-27 weeks later. ${ }^{26}$ In contrast, we have used a single experiment. At 16 weeks, there was an increase in CCPR by 1,2 dimethylhydrazine or $70 \%$ small bowel resection and a decrease in CCPR by calcium; there were no interactions between these factors (Tables III \& IV). The results at 32 weeks (Tables V and VI) confirmed the former findings but also showed significant interactions by calcium or small bowel resection with the carcinogen. Unlike Appleton et al, ${ }^{2627}$ we did not find complete linkage between CCPR and tumour yield. This discrepancy might be explained by differences in the species or sex of the animals used, the extent of small bowel resection $(70 \% v 80 \%)$, or the type of carcinogen used, although it should be noted that 1,2 dimethylhydrazine is the natural precursor of azoxymethane. Alternatively, the discrepancy may be explained by the experimental protocols since the studies of Appleton et $a^{2627}$ could not take into account the interactions between carcinogen and calcium or enterectomy.

The effects of calcium on tumour promotion may be the result of direct or indirect action. In vitro, high extracellular calcium concentrations inhibit the proliferation of human colonic epithelial cells ${ }^{7}$ and several colonic cancer cell lines. ${ }^{37}$ A systemic mode of action has been suggested for calcium ${ }^{4}$ but this seems unlikely from the present study since the serum values of calcium and phosphate were similar in the different groups. Supplementary dietary calcium has been shown in some studies to reduce colonic cell proliferation in man. ${ }^{67910}$ The indirect mechanism of action proposed to explain such an effect implicates the sequestration of bile acids ${ }^{38}$ or other acidic lipids, such as fatty acids. ${ }^{39}$ It seems likely that the proposed mechanisms of action of calcium, involving either the precipitation of calcium bound bile salts or fatty acids as soaps, and the negation of such actions by phosphate is an over simplification. For example, bile acids are probably precipitated from the water fraction of faeces as calcium-phosphate-bile salt complexes. ${ }^{40}$ While increased dietary calcium may increase faecal calcium and the concentration of the bile acid deoxycholate in man, colonic mucosal proliferation may remain unaffected. ${ }^{8}$ In the present study, we have shown an increase in faecal fat excretion (albeit not significant) in the 1,2 dimethylhydrazine treated small bowel resection group given calcium while the CCPR was significantly reduced, yet the tumour incidence was similar.

A similar paradox pertains in the relationship between dietary fibre, colonic cell proliferation, and experimental carcinogenesis. Although most studies $^{2}$ show a protective effect by $20-40 \%$ dietary wheat bran, this also causes appreciable epithelial cell proliferation and mucosal hyperplasia."1 Oat bran has been shown to increase tumourigenesis yet it does not effect colonic cell proliferation. ${ }^{42}$ Indeed Galloway et $a l^{43}$ reported the highest proliferation activity in a dietary experimental group with the lowest incidence of tumours and the converse was also found.

A number of interactions were shown between crypt cell production, 1,2 dimethylhydrazine administration, small bowel resection, and different sites of the intestine. Small bowel resection results in significant changes in the delivery of a variety of luminal factors to the colon including fibre, bile salts, other fats, ions, and water. The precise mechanisms of action and interaction of these factors on carcinogenesis require elucidation in order to understand fully their relationship to colonic cell proliferation. It seems that while an increase in colonic cell proliferation usually precedes and accompanies colorectal carcinogenesis, a reduction of cellular proliferation is not of itself always sufficient to reverse the process. We and others have previously shown increased mucosal cell proliferation in patients with adenomatous polyps or cancer ${ }^{1025}$ and a reduction of mucosal cell proliferation after calcium supplementation. ${ }^{67910}$ Moreover, sulindac has been shown to cause regression of rectal polyps in familial adenomatous polyposis without there being an alteration in the $\mathrm{Ki} 67$ index, an alternative marker of cellular proliferation. ${ }^{44}$ Until long term studies are available, caution should be exercised in the use of colonic cell proliferation indices as markers of neoplastic potential in human dietary intervention studies.

We are grateful for the statistical advice of David Shaw (Statistician, Department of Ophthalmology, University of Birmingham); to Fay Cox and Dilys Thomas (DRH) for preparing the manuscript; and to the Medical Photography Department the manuscript; and to the Medical Photography Department (DRH) for the illustrations. This manuscript is based on a paper presented 1496 .

1 Kune S, Kune GA, Watson LF. Case control study of dietary etiological factors: the Melbourne Colorectal Cancer Study. Nutr Cancer 1987; 9: 21-42.

2 Nicholson ML, Neoptolemos JP, Clayton HA, Heagerty AM. Diet and colorectal cancer. Int Clin Nutr Rev 1988; 8: 180 97.

3 Lyon JL, Mahoney AW, West DW, Gardner JW, Smith KR, Sorenson AW, et al. Energy intake: its relationship to colon cancer risk. F Natl Canc Inst 1987; 78: 853-61.

4 Sorenson AW, Slattery ML, Ford MH. Calcium and colon cancer: a review. Nutr Cancer 1988; 11: 135-45.

5 Alder RJ, McKeown-Eyssen G. Calcium intake and risk of colorectal cancer. Front Gastrointest Res 1988; 14: 177-87.

6 Lipkin M, Newmark H. Effect of added dietary calcium on colonic epithelial-cell proliferation in subjects at high risk for familial colonic cancer. N Engl F Med 1985; 313: 1381-4

7 Buset M, Lipkin M, Winawar S, Swaroop S, Friedman E. Inhibition of human colonic epithelial cell proliferation in vivo and in vitro by calcium. Cancer Res $1986 ; 46$ : 5426-30.

8 Gregoire RC, Storn HS, Yeung KS, Stadler J, Langley S Foire RC, Sten HS, Yeung suplemention on mucosal cell proliferation in high risk patients for colo

9 Rozen P, Fireman Z, Fine N, Wax Y, Ron E. Oral calcium suppresses increased rectal epithelial proliferation of person at risk of colorectal cancer. Gut 1989; 30: 650-5.

10 Barsoum GH, Hendrickse C, Youngs D, Donovan IA Neoptolemos JP, Keighley MRB. Reduction of mucosa crypt cell proliferation in patients with adenomatous polyps by dietary calcium intervention. Brf Surg 1992; 79: 581-3.

11 Williamson RCN, Rainey JB. The relationship between intestinal hyperplasia and carcinogenesis. Scand $f$ Gastroenterol 1984; 19 (suppl 104): 57-76.

12 Nundy S, Malamud D, Obeertrop H, Sczerban J, Malt RA. Onset of cell proliferation in the shortened gut: colonic hyperplasia after ileal resection. Gastroenterology 1977; 72 . 263-6.

13 Williamson RCN, Bauer FLR, Ross JS, Malt RA. Proximal enterectomy stimulates distal hyperplasia more than bypass on pancreatico-biliary diversion. Gastroenterology 1978; 74: or pance $16-23$.

14 Scudamore $\mathrm{CH}$, Freeman HJ. Effects of small bowel transection, or bypass in 1,2-dimethylhydrazine induced rat
intestinal neoplasia. Gastroenterology 1983; 84: 725-31.

15 Rainey JB, Davies PW, Williamson RCN. Relative effects of ileal resection and bypass on intestinal adaptation and carcinogenesis. BrF Surg 1984; 71: 197-202. 
16 Williamson RCN, Bauer FLR, Terpstra OT, Ross JS, Malt RA. Contrasting effects of subtotal enteric bypass, enterectomy, and colectomy on azoxymethane-induced intestinal carcinogenesis. Cancer Res 1980; 40: 538-43.

17 Terpstra OT, Dahl EP, Williamson RCN, Ross JS, Malt RA. Colostomy closure promotes cell proliferation and dimethylhydrazine-induced carcinogenesis in rat distal colon. Gastroenterology $1981 ; 81$ : 475-80.

18 Rainey JB, Maeda M, Williamson RCN. The tropic effect of intrarectal deoxycholate on rat colorectum is unaffected by oral metronidazole. Cell Tissue Kinet 1986; 19: 485-90.

19 Williamson RCN, Bauer FLR, Ross JS, Watkins JB, Malt RA. Enhanced colonic carcinogenesis with azoxymethane in rats after pancreaticobiliary diversion in mid small bowel. Gastroenterology 1979; 76: 1386-92.

20 Williamson RCN, Bauer FL, Oscarson JEA, Ross JS, Malt RA. Promotion of azoxymethane-induced colonic neoplasia by resection of the proximal small bowel. Cancer Res 1978; 38: $3212-7$.

21 Hart P, Stele G, Rayner A, King V, Wilson R. Effect of major small bowel resection on dimethylhydrazine induced bowel carcinogenesis. F Surg Oncol 1981; 18: 87-93.

22 Bristol JB, Wells M, Williamson RCN. Adaptation to jejunoileal bypass promotes experimental colorectal carcinoBr F Surg 1984; 71: 123

23 Lipkin M, Blattner WA, Gardner EJ, Burt RW, Lynch $\mathrm{H}$, Deschner E, et al. Classification and risk assessment of individuals with familial polyposis, Gardner's syndrome and familial non-polyposis colon cancer from $33_{\mathrm{H}}$ - thymidine labelling patterns in colonic epithelial cells. Cancer Res 1984; 44: 4201-7.

24 Deschner EE, Winawer SJ, Katz S, Kahn E. Proliferation defects in ulcerative colitis patients. Cancer Invest 1983; 1: 4l-7.

25 Terpstra OT, Van Blankenstein $M$, Dees J, Ellers GA Abnormal patterns of cell proliferation in the entire colonic mucosa of patients with colon adenoma or cancer. Gastroenterology 1987; 92: 704-8.

26 Appleton GVN, Davies PW, Bristol JB, Williamson RCN. Inhibition of intestinal carcinogenesis by dietary supplementation with calcium. BrF Surg 1987; 74: 523-5

27 Appleton GVN, Bristol JB, Williamson RCN. Increased calcium and small bowel resection have opposite effects on colonic cell turnover. Br f Surg 1986; 73: 1018-21.

28 McSherry CK, Cohen BI, Bokkenhauser VD, Mosbach EH Winter J, Matoba N, et al. Effects of calcium and bile acid feeding on colon tumours in the rat. Cancer Res 1989; 49: 6039-43.

29 Wright NA, Appleton DR. The metaphase arrest technique a critical review. Cell Tissue Kinet 1980; 13: 643-63.

30 Goodlad RA, Wright NA. Quantitative studies on epithelial replacement in the gut. In: Titchen DA, ed. Techniques in digestive physiology. Limerick: Elsevier Scientific Publishers, 1982: 1-23.

31 Gowelock AH, McMurray JR, McLaughlan DM eds. Varley's practical clinical biochemistry. 6th ed. London: Heinemann Medical Books, 1988.

32 Goodlad RA, Levi S, Lee CY, Mandir N, Hodgson H, Wright NA. Morphometry and cell proliferation in endoscopic biopsies: evaluation of a technique. Gastroenterology 1991 101: $1235-41$

33 Cooke T, Kirkham N, Stainthorp DH, Inman C, Goeting N, Taylor I. Detection of early neoplastic changes in experimentally induced colorectal cancer using scannin electron microscopy and cell kinetic studies. Gut 1984 25: 748-55.

34 McGarrity TJ, Peiffer LP, Colony PC. Cellular proliferation in proximal and distal rat colon during 1,2-dimethylhydrazineinduced carcinogenesis Gastroenterology 1988; 95: 343-8.

35 Roncucci L, Ponz de Leon M, Scalmati A, Malagoli G, Pratissoli S, Perini $M$, et al. The influence of age on colonic Pratissoli S, Perini M, et al. The influence of age on

36 Rozen P, Fireman Z, Fine N, Chetrist A, Zajicek G. Rectal epithelial proliferation in persons post sporodic colorectal neoplasia. Cancer Let 1991. 59: 1-8.

37 Guo Y-S, Draviam E, Townsend CM, Singh P. Differential effects of $\mathrm{Ca} 2+$ on proliferation of stomach, colonic and pancreatic cancer cell lines in vitro. Nutr Cancer 1990; 14: 149-57.

38 Wargovich MJ, Vincent EWS, Newmark HL, Bruce RW. Calcium ameliorates the toxic effect of deoxycholic acid on colonic epithelium. Carcinogenesis 1983; 4: 1205-7.

39 Wargovich MJ, Eng VWS, Newmark HL. Calcium inhibits the compensatory proliferative effects of fatty acids on mouse colon epithelium. Cancer Lett 1984; 23: 253-8.

40 Van Der Meer R, Weelberg JWM, Kulpers F, Kleibeuker JH, Mulder NH, Termont DSML, et al. Effects of supplemental
dietary calcium on the intestinal association of calcium, dietary calcium on the intestinal association of calcium,

41 Jacobs LR, Lupton JR. Effect of dietary fibres on rat large bowel mucosal growth and cell proliferation. Am $\mathcal{F}$ Physiol 1984; 246 (Gastrointest Liver Physiol 9): G378-85.

42 Jacobs LR, Lupton JR. Relationship between colonic luminal $\mathrm{pH}$, cell proliferation and colon carcinogenesis in 1,2 , dimethylhydrazine treated rats fed high fibre diets. Cancer Res 1986; 46: 1727-34.

43 Galloway DJ, Jarrett F, Boyle P, Indran M, Carr K, Owen RW, et al. Morphological and cell kinetic effects of dietary manipulation during colorectal carcinogenesis. Gut 1987; 28: $754-63$.

44 Labayle D, Fischer D, Viehl P, Drouhin F, Pariente A, Bories $C$, et al. Sulindac causes regression of rectal polyps in familial adenomatous polyposis. Gastroenterology 1991; 101: 635-9. 